Brit. Heart J., 1964, 26, 709.

\title{
LEIOMYOSARCOMA OF THE INFERIOR VENA CAVA LEADING TO OBSTRUCTION OF THE TRICUSPID VALVE
}

\author{
BY

\section{A. V. HOFFBRAND* AND H. G. LLOYD-THOMAS $\dagger$} \\ From The Medical Unit, the London Hospital, E.1
}

Leiomyosarcoma arising in the veins is rare. We describe the clinical, electrocardiographic, and pathological findings in a patient in whom such a tumour originating in the inferior vena cava eventually caused obstruction of the hepatic veins and of the tricuspid valve.

\section{Case Report}

The patient, a 59 year-old housewife, was admitted to hospital on March 3, 1961. During the preceding month she had noticed dyspnœa on effort, such as climbing 14 stairs, and abdominal distension. Her legs had been swollen for two weeks.

Examination revealed gross œdema of the lower limbs and of the back to the upper thoracic level. There was tense ascites. The liver, which was not tender, had an edge palpable $4 \mathrm{~cm}$. below the costal margin. The spleen was not enlarged. There was a prominent " $a$ " wave in the jugular venous pulse but the mean level of venous pressure was not raised. There was no cardiac murmur. The heart sounds were physiological. The urine contained a trace of protein. When the œdema had later decreased, prominent veins (superficial epigastric, superficial circumflex iliac, and thoraco-epigastric) were visible over the anterior abdominal wall with blood flowing in them from below upwards. Pelvic examination was normal. The blood pressure was $150 / 80 \mathrm{~mm}$. Hg. Chest radiography showed a heart of normal shape and size, normal lungs, and slight unfolding of the aorta. The electrocardiogram (Fig. 1) showed sinus tachycardia, prominent right atrial $P$ waves $(1.5 \mathrm{~mm}$.), and left axis deviation. The QRS complexes in leads I, II, III, CR4, and CR7, respectively measured $8.5,4.0,8.0,12$, and $9 \mathrm{~mm}$. $(1 \mathrm{~cm} .=1 \mathrm{mV})$. Further investigations were: hæmoglobin $13.8 \mathrm{~g}$. $/ 100 \mathrm{ml}$.; white blood cell count 9,700 c. mm. with normal differential; E.S.R. $1 \mathrm{~mm}$. in 1 hour (Westergren); plasma albumin 3.5, globulin $2.5 \mathrm{~g} . / 100 \mathrm{ml}$; thymol turbidity 4 units; zinc sulphate turbidity $4 \cdot 1$ units; serum bilirubin $2.2 \mathrm{mg}$./100 ml.; alkaline phosphatase 22 KingArmstrong units $/ 100 \mathrm{ml}$; prothrombin index between 62 and 76 per cent of normal and not rising after the administration of vitamin K1. Serum glutamic-pyruvic transaminase 32 units per $\mathrm{ml}$.

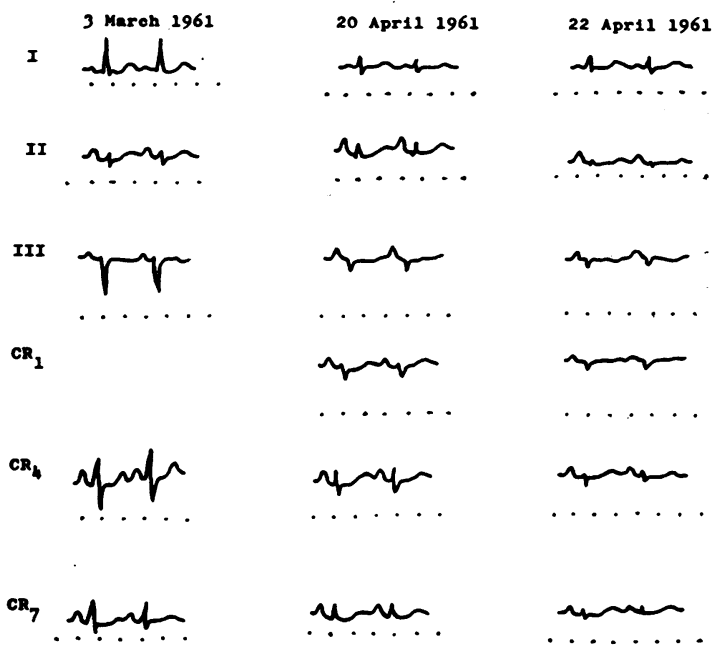

FIG. 1.-Electrocardiograms recorded on the indicated dates. For description and correlation with the clinical condition please see text. It was not possible to obtain records free of somatic tremor, and therefore tracings of the records are reproduced. Intervals between dots equal $0.2 \mathrm{sec}$.

\footnotetext{
* Now at Postgraduate Medical School, London, W.12

† Now at Queen Mary's Hospital, London, E.15
} 
(normal 0-40 units per ml.). Barium swallow showed slight irregularity of the mucosal pattern of the cesophagus possibly due to small varices. The serum urea, sodium, and potassium concentrations were in the normal range.

Progress. Treatment with oral and intramuscular diuretics was accompanied by a reduction in the amount of œdema and a loss of body-weight of some $8 \mathrm{~kg}$. She was, at her own wish, allowed home after three weeks in the ward, on March 24. Deterioration at home was rapid with reaccumulation of ascites and œedema. By the time of readmission on April 18 there had been much alteration in her clinical condition. There was intense peripheral vaso-constriction with cold extremities, small pulse volume, and peripheral cyanosis. The blood pressure had fallen to $90 / 70 \mathrm{~mm}$. $\mathrm{Hg}$. Distension of the veins of the anterior abdominal wall was more obvious. A hard mass measuring about $3 \mathrm{~cm}$. diameter was attached to the right eighth rib in the axillary zone. The mean level of jugular venous pressure had risen and continued to rise to $8-9 \mathrm{~cm}$. above the sternal angle in the last two days of life. The " $a$ " wave remained prominent. The electrocardiogram (Fig. 1) showed striking alterations from the previous record. In the tracing of April 20, the $P$ wave in lead II measured $3.25 \mathrm{~mm}$. The voltages of the QRS complexes were considerably less, measuring $2 \cdot 0,2 \cdot 5,2 \cdot 5,5.0$, and $2.5 \mathrm{~mm}$. respectively, in leads I, II, III, CR4, and CR7. The voltage of the P wave exceeded that of the R wave in leads II and CR7 and equalled it in lead CR4. By April 22 there had been further reduction in the QRS voltage so that it measured only $1 \mathrm{~mm}$. in lead II, 2-3 mm. in CR4, and $1.5 \mathrm{~mm}$. in CR7. The right atrial $P$ wave remained large and it dominated the diminutive $Q R S$ complexes in a striking way. In the last few days of life the patient became oliguric, the serum urea rising rapidly. Death occurred on April 25, less than three months from the date of the first symptom. From the diagnostic point of view it was considered that the course of the illness could be explained by the presence of an intra-abdominal tumour, spreading along the inferior vena cava causing its occlusion and also occlusion of the hepatic veins, with later proliferation of the tumour mass in the right atrium leading to obstruction of the tricuspid valve.

Necropsy. There was slight jaundice and pitting œdema of left ankle and left lower leg. Ecchymoses and purpura were present over upper limbs, chest, and abdominal wall.

Cardiovascular System. There was a mobile mass of soft, pinkish-grey tumour $(4 \times 4 \times 3 \mathrm{~cm}$. $)$ extending through the orifice of the inferior vena cava into the right atrium to reach and almost completely occlude the tricuspid valve and project for approximately $1 \mathrm{~cm}$. into the cavity of the right ventricle (Fig. 2). The tumour appeared to be free from attachment to the endocardium for about two-thirds of the caval opening. Attachment to, and possible infiltration of, the atrial wall was present.

This tumour mass was continuous with a sausage-shaped mass extending down, expanding to $5 \mathrm{~cm}$. diameter, and completely occluding the inferior vena cava as far down as, and including the origins of the hepatic veins, and extending into some of the hepatic vein radicles, several of which showed ante-mortem thrombosis.

Ante-mortem thrombus was also present in both common iliac veins extending upwards in the inferior vena cava to below the renal veins. Both renal veins and the inferior vena cava between them and the hepatic veins were free from tumour or thrombus. A mass of grey soft tumour, $10 \times 10 \times 6 \mathrm{~cm}$., was also present above the right kidney. The right adrenal remained only as a rim $(0 \cdot 2 \mathrm{~cm}$. wide) around the upper smooth surface of this mass. This tumour was continuous with that in the adjacent inferior vena cava.

No other abnormality detected was in the heart (weighing $316 \mathrm{~g}$.), the remaining valves being of normal appearance and circumference.

Respiratory System. Bilateral straw-coloured pleural effusions were present (left $500 \mathrm{ml}$., right $60 \mathrm{ml}$.). The lungs showed moderate œdema. The right eighth rib contained a single tough greyish-white secondary deposit at its centre.

Abdomen. There were $360 \mathrm{ml}$. of clear brownish-yellow ascites. The liver had a smooth capsule and the subcapsular and cut surfaces showed coarse mottling due to the presence of yellow and red areas up to $2 \mathrm{~cm}$. across. There were no œsophageal varices. The spleen $(129 \mathrm{~g}$.) showed a dark firm pulp with indistinct malpighian bodies. There was fluid blood in the oesophagus, stomach, duodenum, and upper jejunum but no ulceration of these structures. There was a single intramural fibromyoma, $1 \mathrm{~cm}$. in diameter, in the uterus.

All other organs appeared normal. In particular, the kidneys showed no evidence of congestion or infarction.

Microscopy. The sections showed highly cellular, poorly differentiated tumour composed predominantly of whorls and strands of fusiform cells. Nuclei were vesicular, elongated with blunted ends. Occasional giant cells were identified and a few mitoses were present. Similar tumour was present in the inferior vena 


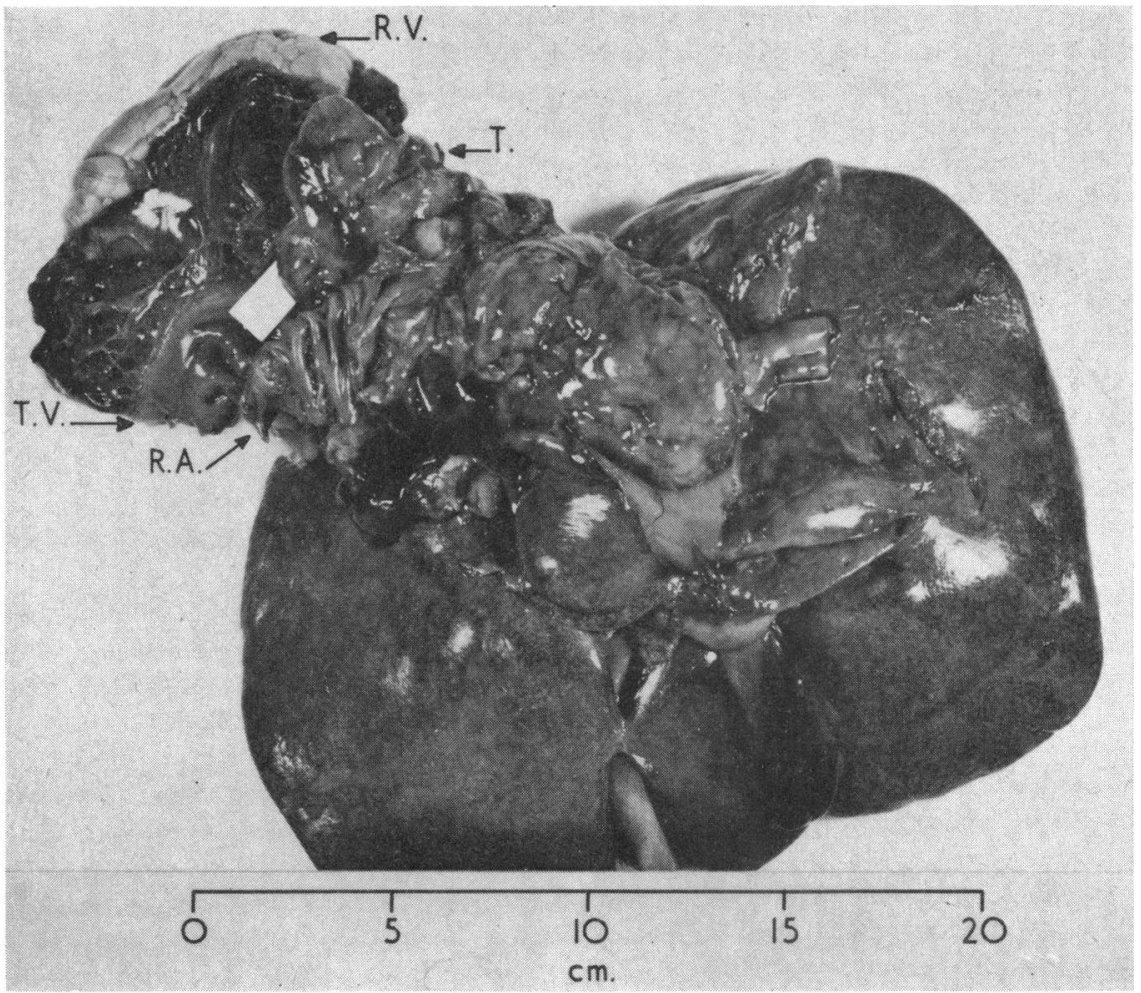

FIG. 2.-Posterior view of liver, inferior vena cava, and heart showing right atrium (R.A.), tricuspid valve (T.V.) and right ventricle (R.V.). The tumour (T) occludes the inferior vena cava and extends (over white marker) beyond the tricuspid valve into the right ventricle. The uppermost portion of the specimen corresponds to the apex of the right ventricle.

cava (Fig. 3 and 4), invading the wall of the right atrium and as a mass beneath the right adrenal. Secondary tumour in the right eighth rib had a similar structure.

Special staining with Hart's elastic and van Gieson's stain showed a few collagen fibres between the cells and, with phosphotungstic acid hæmatoxylin, occasional longitudinal striations in the cells (Fig. 4). The features suggest leiomyosarcoma.

In some parts, the liver showed zonal loss of parenchyma and replacement by accumulation of hepatic cell debris, red corpuscles, and pigment-containing phagocytes, around hepatic venous radicles. There were associated surviving enlarged non-pigmented periportal cells (Fig. 5). Bile thrombi were seen in the canaliculi between the cells adjacent to the necrotic foci. Other parts of the liver showed enlarged parenchymal cells with narrow sinusoids, the cells sometimes forming plates more than one cell thick (Fig. 6). Our case did not show the sharp edge to the regenerating foci which was described by Murray and Kimmel (1949). We interpret our findings as representing rather recent occlusion of the hepatic venous ostia and this accorded with the clinical history.

The kidneys revealed slight interstitial œdema but no other abnormality. The lungs showed fairly severe œdema. The uterus contained a single fibromyoma which was of typical appearance without evidence of malignancy.

\section{Discussion}

Leiomyosarcoma is a moderately rare tumour. According to Shuman (Anderson, 1961), there are 462 cases on the file of the Armed Forces Institute of Pathology, $125(27 \%)$ of which arose in soft tissue sites. Of these, only 8 arose in the venous system. In the general literature, Thomas and 


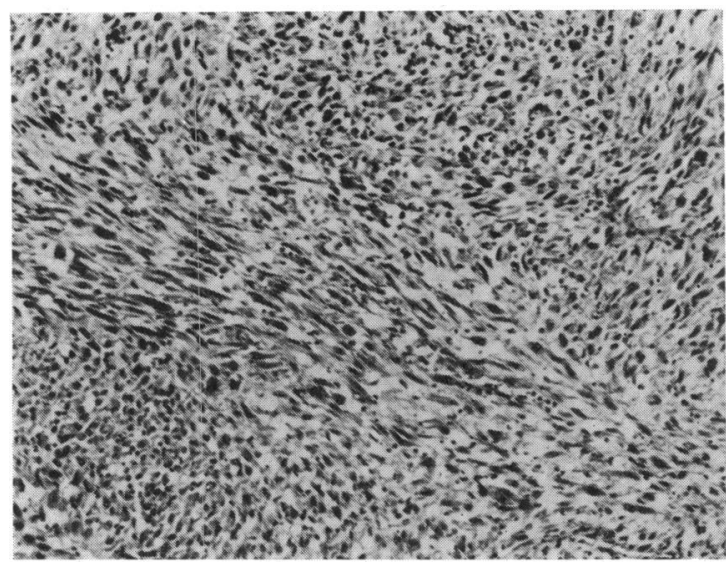

FIG. 3.-Section of the tumour in the inferior vena cava. Spindle-shaped cells arranged in interlacing bundles may be seen. (Hæmatoxylin and eosin. $\times 98$.

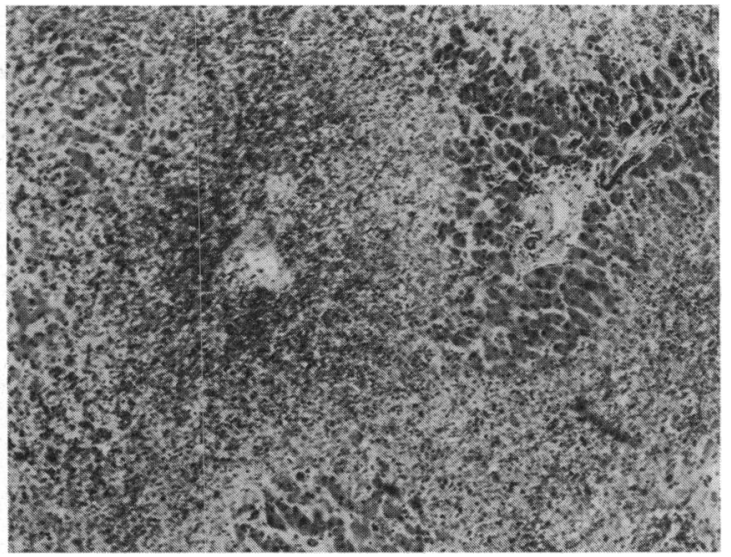

Fig. 5.-Low power view of liver. Extensive necrosis is present round the hepatic vein radicle with surviving periportal parenchymal cells in the upper right-hand part of the field. (Hæmatoxylin and eosin. $\times 54$.)

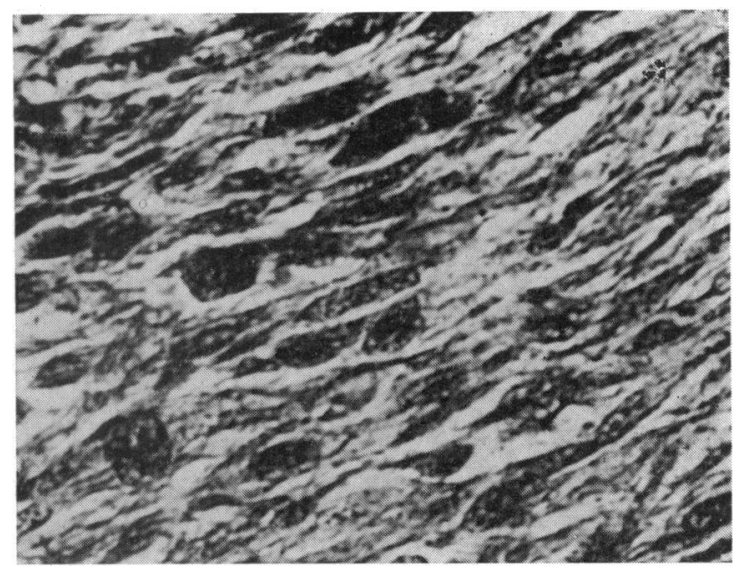

FIG. 4.-High power view of the tumour. Longitudinal fibrils may be seen in some of the cells extending from either end of the nucleus. (Phosphotungstic acid hæmatoxylin. $\times 705$ )

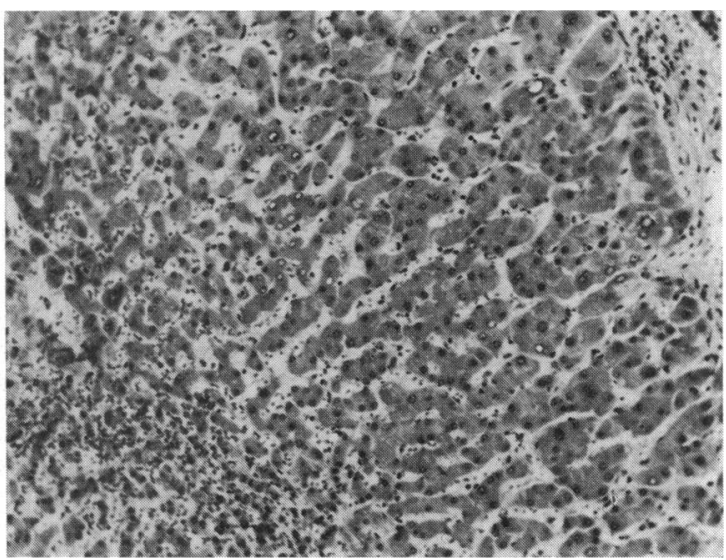

Fig. 6.-Higher power view of another zone of the liver to show surviving periportal cells with occasional plates thicker than normal denoting that regeneration of heptic parenchymal tissue is occurring. (Hæmatoxylin and eosin. $\times 105$.)

Fine (1960) refer to 26 case reports of smooth muscle tumours arising from the media of veins and add 2 of their own. Of these 28, 16 were malignant and 12 were benign. Leiomyosarcoma of the inferior vena cava has previously been reported 14 times. The features of these cases, together with those of the present case, are summarized in the Table.

In general, it is a slowly growing tumour and metastases have only been reported in 5 cases including the present one. The symptoms are mainly due to obstruction to blood flow in the inferior vena cava and vary according to the level at which this occurs. Tumours of the lower or middle thirds may be symptomless or produce mild œdema of the lower extremities. In the majority of cases, the renal veins remain patent. At these levels, symptoms are principally due to the tumour itself, consisting of lower abdominal pain or pain in the back. In one of these cases (Cope and Hunt, 1954), the tumour was successfully excised. 
TABLE

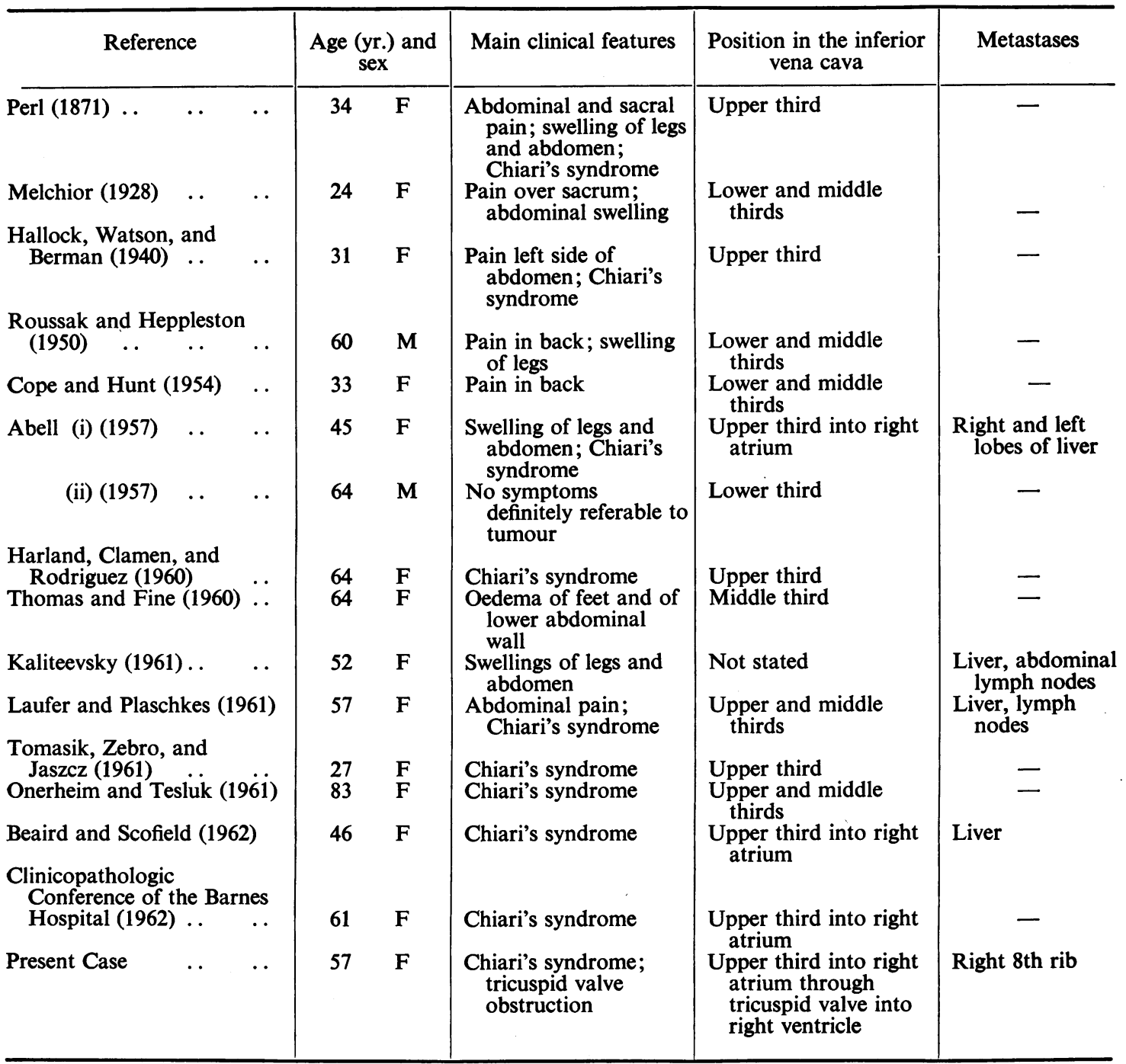

Tumours of the upper one-third tend to present with features of the Budd-Chiari syndrome (Budd, 1846; Chiari, 1899). These are abdominal pain, an enlarging liver, progressive hepatic failure, œdema, and ascites. The syndrome is caused either by direct tumour extension into the hepatic venous ostia or, more commonly, to thrombosis at the hepatic venous ostia or in the smaller hepatic vein radicles. The clinical features and pathological findings in the liver then depend largely on whether the hepatic venous occlusion is a rapid or slowly developing event as described by Parker (1959). In some of those cases with tumour in the upper one-third of the inferior vena cava, minor symptoms have been present for a year or two before a rapidly downhill course with progressing hepatic failure has supervened, suggesting that the tumour itself is slow growing, and that it is only when hepatic venous occlusion occurs that more obvious and rapidly fatal features supervene.

The electrocardiogram in our patient showed increasing enlargement of the right atrial $\mathbf{P}$ waves 
due to the progressive obstruction of outflow from the atrium. The QRS voltage became very reduced, and this is probably to be related to diminished cardiac work and, as the voltage reduction in lead II is particularly severe, to alteration in the QRS vectors consequent upon distension of the right atrium. These changes developed over the course of approximately seven weeks. In the case of right atrial myxoma reported by Adams et al. (1961) the electrocardiogram showed the development of large right atrial P waves associated with great reduction in the QRS voltage in leads I, II, and III over the longer interval of some three years. The $P$ waves became large in three weeks in the case showing obstruction of the mitral valve by a secondary deposit from an ovarian tumour (Lloyd et al., 1961). Frankenfeld, Waters, and Steiner (1960) described similar enlargement of the $\mathbf{P}$ waves in a patient with bilateral atrial myxomas and commented upon the reduction in the QRS voltage. Observations on the reduction of the QRS voltage in tumour obstruction of the heart have been recorded by other observers (Field, Donovan, and Simon, 1945; Lekisch, 1957; Ellis, Mankin, and Burchell, 1958). Levinson and Kincaid (1961) have described regression of the $P$ waves and increase in the QRS voltage in a patient from whom a right atrial myxoma had been successfully removed.

\section{Summary}

The clinical features of a patient with leiomyosarcoma of the inferior vena cava leading to its obstruction and to obstruction of the tricuspid valve are described. The electrocardiogram showed alterations that could be correlated with the clinical condition. The macroscopic and microscopic findings at necropsy are described and the 15 previously reported cases of leiomyosarcoma of the inferior vena cava have been reviewed.

Our thanks are due to Professor Clifford Wilson and Professor I. Doniach for allowing us to report this case; to Dr. H. K. Weinbren for much helpful advice; and to Mr. A. J. King for the photomicrographs.

\section{References}

Abell, M. R. (1957). Leiomyosarcoma of the inferior vena cava. Review and report of two cases. Amer. J. clin. Path., 28, 272.

Adams, C. W., Collins, H. A., Dummit, E. S., and Allen, J. H. (1961). Intracardiac myxomas and thrombi. Amer. J. Cardiol., 7, 176.

Anderson, W. A. D. (1961). Pathology, 4th ed., p. 472. Mosby, St. Louis.

Beaird, J. B., and Scofield, G. F. (1962). Budd-Chiari syndrome. Arch. intern. Med., 110, 435.

Budd, G. (1846). On Diseases of the Liver, p. 151. Lea and Blanchard, Philadelphia.

Chiari, H. (1899). Ueber die selbständige Phlebitis obliterans der Hauptståmme der Venae hepaticae als Todesursache. Beitr. path. Anat., 26, 1.

Clinicopathologic Conference of the Barnes Hospital (1962). An unusual cause of rapidly progressive hepatic failure. Amer. J. Med., $32,599$.

Cope, J. S., and Hunt, C. J. (1954). Leiomyosarcoma of the inferior vena cava. A.M.A. Arch. Surg., 68, 752.

Ellis, F. H., Mankin, H. T., and Burchell, H. B. (1958). Myxoma of the atrium: Successful surgical treatment in two cases. Med. Clin. N. Amer., 42, 1087.

Field, M. H., Donovan, M. A., and Simon, H. (1945). Primary tumor of the left auricle simulating mitral stenosis. Amer. Heart J., 30, 230.

Frankenfeld, R. H., Waters, C. H., and Steiner, R. C. (1960). Bilateral myxomas of the heart. Ann. intern. Med., $53,827$.

Hallock, P., Watson, C. J., and Berman, L. (1940). Primary tumor of the inferior vena cava, with clinical features suggestive of Chiari's disease. Arch. intern. Med., 66, 50.

Harland, W. A., Clamen, M., and Rodriguez, V. M. (1960). Leiomyosarcoma of the inferior vena cava with clinical features of Chiari's syndrome. Canad. med. Ass. J., 83, 1064.

Kaliteevsky, P. F. (1961). Retroperitoneal leiomyosarcoma originating from the wall of the I.V.C. [in Russian]. Arkh. Pat., 23, no. 3, p. 77.

Laufer, A., and Plaschkes, J. (1961). Primary leiomyosarcoma of the inferior vena cava. Path. et Microbiol. (Basel), 24, 72.

Lekisch, K. (1957). Myxoma of the left atrium: Report of a case. Ann. intern. Med., 46, 982.

Levinson, J. P., and Kincaid, O. W. (1961). Myxoma of the right atrium associated with polycythemia. New Engl. J. Med., 264, 1187.

Lloyd, A. M., Anderson, D. J., Stuckey, D. S., Kalokerinos, J., Epps, R. G., Freeman, Z., Durie, E. B., Kraus, O., Raven, J. L., and Jones, K. O. A. (1961). Clinical pathologic conference. Amer. Heart J., $61,698$.

Melchior, E. (1928). Sarkom der Vena cava inferior. Dtsch. Z. Chir., 213, 135.

Murray, J. F., and Kimmel, S. A. (1949). Chiari's syndrome: Report of a case. S. Afr. med. J., $23,851$. 
Onerheim, W. O., and Tesluk, H. (1961). Leiomyosarcoma of the inferior vena cava. Arch. Surg., 82, 395.

Parker, R. G. F. (1959). Occlusion of the hepatic veins in man. Medicine (Baltimore), 38, 369.

Perl, L. (1871). Ein Fall von Sarkom der Vena cava inferior. Virchows Arch. path. Anat., 53, 378.

Roussak, N. J., and Heppleston, J. D. (1950). Obstruction of the inferior vena cava by a leiomyosarcoma. Lancet, 2, 853.

Thomas, M. A., and Fine, G. (1960). Leiomyosarcoma of veins: Report of 2 cases and review of the literature. Cancer (Philad.), 13, 96.

Tomasik, B., Zebro, T., and Jaszcz, W. (1961). Malignant leiomyoma of the inferior vena cava with clinical picture of the Budd-Chiari syndrome. [in Polish]. Nowotwory, 11, 443. 